JOURNAL

of Health Inequalities

\title{
Eugenic abortion and in vitro fertilization in the context of state policy aimed at increasing fertility rates and promoting birth-defect-free childbearing in Poland - a review
}

\author{
Andrzej Wojtyła, Przemysław Biliński \\ Higher Vocational State School in Kalisz, Poland
}

\begin{abstract}
Recent waves of popular protests against the law for limiting abortion has hit Poland in the wake of Parliamentary decisions, firstly adopting and then repudiating a draft civic amendment to the Act on 'Family planning, human embryo protection, and circumstances for permitting abortion. This had been civically introduced as a proposed total ban on induced abortion in Poland. In the past, so called 'Abortion Act' of 1956, brought about 50\% abortion rate of all pregnancies in Poland and other East Central European Countries. Upon changing the law in 1993, the number of abortions in Poland have decreased significantly down to the low rates observed on most Western European countries. At the beginning of the 1990s, the average Polish woman bore more than two children, thereby ensuring demographic renewal. At present, however, the average Polish women gives birth to 1.3 children which leads to depopulation. At the start of the 1990s, the average Polish woman gave birth to her first child at 23.5 years of age, whereas now the age has shifted to almost 29 years. In such a context, current discussions have elevated the issues of in vitro fertilization (IVF), as well as eugenic abortion due to birth defects.
\end{abstract}

KEY WORDS: abortion, in vitro fertilization, demography, birth rate.

ADDRESS FOR CORRESPONDENCE: Prof. Andrzej Wojtyła, Higher Vocational State School in Kalisz, 4 Nowy Świat Street, 62-800 Kalisz, Poland, e-mail: a.wojtyla55@gmail.com

Recent waves of popular protests against the law for limiting abortion has hit Poland in the wake of Parliamentary decisions, firstly adopting and then repudiating a draft civic amendment to the Act on 'Family planning, human embryo protection, and circumstances for permitting abortion' [1]. This had been civically introduced as a proposed total ban on induced abortion in Poland [2]. At present, abortion on societal grounds is banned.

The law makes abortion legally permissible only in the following circumstances:

1) whenever the pregnancy threatens the life or health of the mother, as confirmed by a Medical Practioner not involved in the given abortion,

2) if prenatal investigations demonstrate substantial and irreversible damage to the embryo or the presence of an incurable life threatening illness,
3) if justifiable suspicion exists that the pregnancy resulted from an illegal act; as confirmed by a state prosecutor.

Up to 2 years of imprisonment is the current penalty for any medical doctor that performs an illegal abortion. In Poland, societal abortion was legally allowed between 1956-1993, which had been widely exploited by women as a method of birth control resulting in poor State family-planning policies. Indeed, the governments of the time had failed to introduce any policies for simultaneously restricting abortion coupled with promoting and subsidizing family planning [3]. The then current and so called 'Abortion Act' of 1956, has brought about 50\% abortion rate of all pregnancies in Poland. For example, shortly after passing the Act on permitting induced miscarriage (abortion), the numbers of such proce- 
dures were 233,000 for every 660,900 live births in 1960 (a 352.5 abortion ratio [1]), i.e. 352 abortions per 1000 live births. In 1962, the figures were 233,000 abortions for 599,505 live births (453.7 abortion ratio), whilst for 1981 there were 230,070 abortions for 599,505 live births (453.7 abortion ratio) [4, 5]. Similar and even higher abortion rates had been observed in other countries of Central and Eastern Europe. For instance, in the Ukraine there were 733,183 live births and 1,112,734 abortions carried out in 1981 giving an abortion ratio of 1517. For the same year in Czechoslovakia, there were 237,734 births and 103,517 abortions performed (435.4 abortion ratio), whilst in Bulgaria there were 124,372 births and more than 152,500 abortions, and for Romania in 1982 , over 344,000 births and 468,000 abortions. These are official data, which in Poland's case may actually be underestimated, because this country was the only one in Central and Eastern Europe that at the time possessed a well-developed market for private gynecological surgeries, and thus a large number abortions went unrecorded [6]. Most other European countries had abortion ratios ten-fold lower. Such data suggests that the populations of Central and Eastern European countries would have been at least doubled if these abortions had not taken place. Accusations made by the authorities of the Soviet Union that there had been a deliberate denuding of the populations in these countries after World War II, by means of abortion, is thereby not without foundation. Upon changing the law in 1993, the number of abortions in Central and Eastern European countries have decreased significantly down to the low rates now observed on Western European countries [7]. Abortion rates remain high in those European countries from this region, which did not change their legislation on this issue following the transformations of the 1990s. For instance, in Russia, out of $1,900,000$ annual births $1,000,000$ are aborted, and in Bulgaria, out of 67,000 births per annum, 28,000 are aborted, with a similar situation existing in Romania. Despite wide access to other methods of family planning, these countries still use abortion as a means for birth control [8].

Protests held in Poland, organized mainly by feminists, have found a support in Europe and the rest of the world, as likewise is the case of international organizations in this area [9]. Within the 23 years since the 1993 Act, there have been occasional anti-Act protests and demonstrations, mainly occurring whenever there has been a change of government coalitions, which - it should be stressed - were mostly directed at liberalizing the Act's provisions. At the present however, most organized protests and demonstrations are in favor of keeping the Act's actual provisions as they stand. As the then Minister of Health and Social Welfare, during the time when the Act was passed, I feel its co-author and therefore I do not wish to be a party in any ideological discussions on this topic, since my views would certainly not be fully objective. Given the political conditions in Poland of the early 90's, this Act, in my opinion, was the only compromise that could have been reached where it was intended to change the 1956 Act that had allowed abortion on demand. However, since 1993, over two decades later, the demographic situation has altered, as has the procreative behavior of Poles and Polish families [10].

\section{THE CHANGES IN PROCREATIVE BEHAVIOR OBSERVED IN POLAND SINCE 1993}

This changes has mainly come about through a modification in approach, which has largely arisen because there have been no population policies adopted based upon scientific evidence, nor on the experience accrued by other countries. Over these 20 years or so, a policy of liberal economic development has been adopted in Poland but at the same time, key demographic aspects decisive for the future of our nation have been ignored/ forgotten. Such errors have been borne out by the statistics on fertility [11]. At the beginning of the 1990s, the average Polish woman bore more than two children, thereby ensuring demographic renewal, i.e. the so-called linear reproductive rate [12]. This had assured to keep Poland's population at the same level. At present, however, the average Polish women gives birth to 1.3 children, which leads to depopulation and is supported by demographic projections [13]. For the last 23 years, this problem has not been investigated, nor have any concrete political initiatives been taken in this area, where any legislative measures were fragmentary, chaotic, and brought upon the public without any professional analysis of the situation. The politics during this period led to the other disturbing developments in this regard. At the start of the 1990s, the average Polish woman gave birth to her first child at 23.5 years of age, whereas now the age has shifted to almost 29 years [14]. In such a context, current discussions have elevated the issues of in vitro fertilization (IVF), as well as eugenic abortion due to birth defects.

\section{NATURALLY INHERENT LIMITATIONS TO WOMEN'S NATURAL CHILDBEARING CAPACITY/CAPABILITY}

It should be realized that women's capacity for producing offspring is based on having a limited number of reproductive cells that are capable of fertilization [15]. When a female is newborn, she possesses about 1-2 million reproductive cells (oocytes). In the following years of life, these cells continuously disappear [16]. During adolescence, the average girl has only 300-500 thousand of these cells. Furthermore, greater majority of these oocytes are themselves incapable of undergoing fertilization and allowing childbearing [17]. Throughout their childbearing years, i.e. from adolescence to about 40-45 years, women only have around 400-500 oocytes (female gametes) capable of fertilization and pregnancy; this being 
a natural limitation to women's fertility [18]. The process where reproductive cells capable of pregnancy disappear, also changes in severity over the childbearing years [19]; this becomes more pronounced with the age increasing [20]. In scientific terms, it is called a gradual loss of the so-called 'ovarian reserve', which determines the ovary's capacity for providing egg cells capable of fertilization [21]; its rate of loss being linear [22]. For example, at 30 years' age, this reserve amounts to $12 \%$ of the reproductive potential at puberty, whereas at 40 years' age, it falls to just 3\%. This significantly reduces women's childbearing capability/capacity. At the age of 20 years, only $2-4 \%$ of those women wishing to conceive are unable to do so, and at 25 , these numbers rise to $3-6 \%$, whereas at 35 years every fifth woman is unable to have offspring (17-22\% according to various sources). At the age of 40 , half of those women wishing to conceive are unable to do so [23]. In many European countries, where women's childbearing ages follow similar patterns, IVF has begun to be widely adopted [24]. Nevertheless, the impact of such interventions on demographic processes is minimal and insignificant, and the effectiveness of such types of intervention is very low $[25,26]$. Furthermore, the economic costs and the health burden on future generations born in this way are enormous [27].

\section{WOMEN'S POSTPONEMENT OF CHILDBEARING}

The possibilities of IVF have generated much of an interest and is mainly due to women's late entry into their childbearing life-span, which is linked to female childbearing postponement [28]. A man's age, however, is relatively not so much important for childbearing because sperm is cyclically produced throughout life (post-adolescence). The issue raised by proponents of IVF that infertility is a sign of modern times resulting from environmental factors, is at present poorly proven in scientific terms [29]. In contrast, evidence that IVF adversely affects the health of offspring and subsequent generations is now well proven [30]. Another factor associated with female childbearing postponement, which encroaches onto the discussion on abortion and IVF, is the issue of eugenic abortion arising from serious birth defects found intrauterine in the fetus. As alluded to at the beginning, the existing law in Poland makes provision for such cases. In keeping with a woman's decreasing childbearing capability/capacity with age, egg quality also decreases, which is thereby responsible for increased risks of birth defects in the fetus and newborn [31]. Reasons for this are a greater probability for disorders in cell division manifest in the oocyte and embryo, post-fertilization, giving rise to developmental pathologies [32]. Examples of such findings are reflected in the statistical outcomes regarding these disorders, in that $10 \%$ of a woman's genetic material in oocytes are susceptible at ages below 35 years, which then rises to $30-40 \%$ at $40-43$ years' age, whilst after 45 years, all such genetic material becomes susceptible to chromosomal aberrations, henceforth leading to birth defects.

\section{BIRTH DEFECT RATES DEPEND ON THE MOTHER'S AGE}

In older women, this becomes apparent in the fetus and newborn leading, amongst others, to conditions such as the Down syndrome. In terms of statistics, mothers who became pregnant aged 20-25 years will expect to have one fetus per 1,400 with this type of genetic disorder; at 25-29 years, one per 1,100; at 30-31 years, one in 900, and from thence onwards such risk rises in linear fashion; at 32 years, one in 750; at 33 years, one in 420 ; at 35 years, one in 250; at 40 years, one in 75 , whilst at above 45 years the risk becomes one in 20 , i.e. every $20^{\text {th }}$ women can expect that her fetus will be burdened with this disorder [33]. Thus, compared to a 25-year-old woman, the risk of bearing a child with Down syndrome rises by $64 \%$ for a 30 -year-old woman (this, it should be remembered, is currently the average age, at which women bear their first child in Poland). Other common birth defects in the fetus and newborn demonstrate similar trends; i.e. the older the mother, the higher the risk in offspring being burdened with serious genetic defects [34]. Studies show that if all women gave birth to children when aged under 30 years, then the number of Down syndrome cases would be reduced by over $60 \%$. This article confines itself to the causes of birth defects in women because studies demonstrate that over $90 \%$ of birth defects arise from abnormalities during ovarian egg cell division in the mother [35]. Nature itself eliminates individuals burdened with serious defects, as evidenced by the fact that nearly $90 \%$ of such fetuses die due to spontaneous abortion and a further proportion, almost $10 \%$, are stillborn [36]. Out of this, the minimal numbers remaining are born alive. Current techniques employ intrauterine surgery for fetal birth defects, which allow those with serious defects to survive and to be born alive. In certain cases, after birth, some defects are corrected allowing such newborns to survive. Human intervention in the natural processes occurring for these cases is by all means beneficial and humane. It is noteworthy that in 1960, those persons born with this syndrome lived an average of 12 years, which by $1983 \mathrm{had}$ increased to 25 years, reaching a present level of almost 49 years. Such changes are linked to improvements in living conditions and recent progress made in developing new medical technologies. The increasing rates of infertility with maternal age, along with increased risks of serious birth defects arising in offspring, is a clear and unambiguous fact that has been scientifically proven. This is the outcome of human interventions in natural childbearing, which has involved birth planning and in the making of free reproductive choices of the moment when to conceive [37]. Having readily accessible methods of contraception is the causal factor [38]. As a consequence, the proportion of infertile women increases, 
and upon becoming pregnant, there are increased rates of natural miscarriage, stillbirths, and serious genetic birth defects in fetuses and newborns. And it therefore has followed, that the ongoing debate on abortion eugenics and infertility has now become rather intense.

\section{INSTEAD OF CURATIVE/ETIOLOGICAL SOLUTIONS, ATTEMPTS AT PALLIATIVE/ SYMPTOMATIC APPROACHES}

Up till now, both the executive and legislative branches of the state apparatus have not addressed the root causes of these issues but have rather made attempts to solve their consequences, as has been demonstrated by introducing free access to IVF. With the best good will in the world and also for humanitarian reasons, some organized societal groups have proposed a statutory limit for abortion in cases of severe or fatal birth defects. Likewise, this constitutes an attempt in solving the consequences but not the cause of the increasing numbers of fetal birth defects, which as stressed before, arises from direct human intervention in the natural order of ongoing processes. Above all else, family-friendly policies should be introduced, so that young women are encouraged to bear children. By such means, the causes of infertility can be eliminated, and rates of birth defects in fetuses and newborns decreased. One does not have to look far for examples of such a policy. The Scandinavian countries have addressed this problem and demographic renewal is slowly being restored [39]. Also by following a pro-family policy in the Ukraine, the average childbearing age today is now less than 24 years in that country [40]. This in fact was the average age, at which Polish women gave birth to their first child 26 years ago, in 1990 [41]. At the moment, Ukrainian women on average give birth to 1.5 children, which is more than in Poland (1.3 children) [42]. Such an outcome was achieved thanks to the Ukrainian 'Orange Revolution' where pro-family policy reforms were introduced, particularly focused on encouraging young women to have more offspring [43]. The leaders of the current government in Poland have positively responded to this challenge by introducing public education programs on these issues. The task of the successfully undertaken programme, the " 500 Plus", is to increase birth rates in Poland, targeting those women born in the demographic high 'baby boom' years of the 1980s, whose childbearing capabilities/capacity are soon ending. These women usually already have children, and the program is aimed to encourage the expansion of their families. This is a correct, proper, and necessary intervention for improving the disastrous demographic indicators in our country. Data from this year shows that the intended demographic effect will indeed be brought about. However, in those women born during the demographic low of the 1990s who are now entering their childbearing ages, the state policy must be directed towards encouraging these young women, including students, to bear children and raise families. By such means, the modifiable causes of infertility can be reduced along with the large number of birth defects in fetuses and newborns, which arise when motherhood is postponed.

\section{OTHER MODIFIABLE CAUSES OF INFERTILITY AND BIRTH DEFECTS}

These constitute the risk-bearing behavior of women during their childbearing years that also includes men. Studies have demonstrated that smoking cigarettes, overweight, underweight, unhealthy diet, and excessive alcohol consumption can cause problems with infertility, even in a healthy man or woman [44]. There is however a shortage of research on this subject in Poland. Nevertheless, the limited data that is available on this subject demonstrates that almost $1 / 3$ of women who become pregnant are current smokers [45]. Despite this, most women give up smoking once the pregnancy has been confirmed by a gynecologist, which usually occurs in around the $8^{\text {th }}$ week of the pregnancy. However, the embryo and fetus during these very important early weeks of pregnancy, grows in conditions of oxygen deficiency, which limits their growth and development. Moreover, the embryo and fetus are exposed to the harmful substances contained within tobacco smoke, which can lead to several defects. It transpires that there is 2-3-fold higher risk of some birth defects in the fetuses of actively smoking women, whilst this risk is 1.5 times higher in women exposed to passive smoking [46]. Studies have also shown that $31 \%$ of female smokers suffer from infertility anyway, whilst for men smokers, the number of birth defects in their offspring is statistically high as well as these men suffering from infertility problems [47]. Introducing anti-smoking campaigns aimed at young people of childbearing age is thus a matter of urgency in Poland. Nonetheless, this problem has not yet really been properly investigated. Some initiatives in this area were taken in 2006 and 2007, but were later abandoned. Another factor causing birth defects in fetuses and newborns is women's alcohol consumption in their childbearing age. And here the indicators in Poland are well disturbing [48]. Over $90 \%$ of women who become pregnant, consume alcohol in various guises. What is worse, is that the same numbers consume alcohol during pregnancy, although the quantity and consumption rates are smaller [49]. Studies have demonstrated that even the minimum amount of alcohol can cause the so-called fetal alcohol syndrome (FAS), from which in many cases cause serious birth defects. Polish women of childbearing age remain unaware of this problem and, what is worse, so are nearly $3 \%$ of gynecologists providing healthcare to women, advising them to drink small amounts of red wine during pregnancy. Added the small proportion of doctors that are unable to recognize FAS after birth and subsequent years of life, the situation appears even more disturbing. Introducing health promotion programs for 
women of childbearing age is therefore necessary, which since 2007 has not been done in our country.

Pregnant women contracting infections may also be the cause of severe birth defects, especially in the earliest phases of embryonic and fetal development. For example, the influenza virus constitutes a threat to the mother. However, when becoming pregnant, women are unaware of this as is evidenced by the alarmingly low vaccination rates against this disease, being in fact one of the main causes of severe birth defects in fetuses and newborns that can be easily eliminated. In 2006-2007, the Polish Government launched an educational campaign, which very rapidly bore fruit leading to clear improvements in vaccination against influenza in Poland. Since that time however, education in this field has not been evident.

Many years ago, a program was introduced in Poland to combat neural tube defects in fetuses and newborns, which consisted of providing and disseminating folic acid preparations to women during pregnancy. Studies had previously shown that folic acid deficiency in women before conception and during the first moments after fertilization is essential for healthy embryonic and fetal development, whilst a deficiency can result in severe birth defects. Nonetheless, when women become pregnant they begin to take folic acid too late; 8 weeks already elapsing when the gynecologist confirms their pregnancy. In addition to the beneficial effects of folic acid are the essential B group vitamins where women's consumption rates of this vitamin prior to becoming pregnant is minimal, and becomes only $60 \%$ after the pregnancy is confirmed.

Another factor of concern is that more than half of young women with a normal body weight at the time of conceiving use various methods of weight loss. This is stopped only when the pregnancy is confirmed by a gynecologist. As a result, during the critical early stages of development, the fetus is under conditions of malnutrition. In such ways, irreversible changes may occur to the embryo and fetus. Indeed, this situation arises in over $80 \%$ women having planned pregnancies in Poland. Perhaps such findings are surprising compared to the data from other countries where unplanned pregnancy rates are much higher (e.g. in the USA, 50\% of pregnancies are unplanned) [50]. The fact that a high proportion of women and families in Poland plan their motherhood, contradicts the notion of supposedly high numbers of unwanted pregnancies that are the subject of illegal abortions. The presented epidemiological facts clearly indicate that this premise is false.

\section{POPULATION-BASED EPIDEMIOLOGICAL STUDIES IN POLAND ON YOUNG PEOPLE'S HEALTH BEHAVIOR DURING CHILDBEARING AGE AND FOR PREGNANT WOMEN}

During 2006-2007, studies were launched in Poland for monitoring health behavior of young people and pregnant women, according to the methodology described in this issue of the journal. Poland and countries of the former Soviet-Bloc had a unique in the world supervision system SANEPID that was centrally organized with facilities distributed uniformly throughout a given territory. In Poland, there is one SANEPID station for around every 100,000 of the population. Station employees are well versed on the health problems concerning their local population and published studies have taken advantage of this; both for young people of childbearing age (in schools and secondary schools) as well as those attending universities. Study subjects were chosen at specified years, consisting of a representative sample of more than 10,000 young people, with SANEPID employees conducting a survey by interview. Pregnant women were however surveyed on a selected day of each year in all Polish hospitals after just giving birth. To avoid any seasonal bias in birth rates, the survey was performed in a different quarter of each year. This approach proved to be very effective and cheap, and is recommended to other Central and Eastern Europe countries for performing easy and useful monitoring. In 2017, this monitoring study will be repeated. We also plan to continue and expand it to other countries in this part of Europe. Our intention is to shortly launch such studies in the Ukraine.

\section{MANDATORY PRENATAL STATE-POLICY FOR PRIMARY PREVENTION}

State policies regarding family matters should rely on employing legal solutions for encouraging Polish women and their families to start conception early in their childbearing life span years, thereby, increasing the reproductive capabilities/capacity of women as well as reducing infertility and reducing rates of severe birth defects. This initiative, together with the other so-called modifiable causes of infertility and birth defects, is critical in dealing with the much publicized problems with in-vitro fertilization along with eugenic abortions performed because of birth defects.

\section{DISCLOSURE}

Authors report no conflict of interest.

\section{References}

1. Ustawa $z$ dnia 7 stycznia 1993 r. o planowaniu rodziny, ochronie płodu ludzkiego i warunkach dopuszczalności przerywania ciąży. Dz.U. 1993 nr 17 poz. 78 [Journal of Laws of the Republic of Poland 1993, nr 17, poz. 78. Law from 7 January 1993 regarding the family planning, human embryo protection and conditions of permissibility of abortion]. Available from: http://isap.sejm. gov.pl/DetailsServlet?id=WDU19930170078 (accessed 5 November 2016).

2. Ustawa z 2016 r. o zmianie ustawy z dnia 7 stycznia 1993 r. o planowaniu rodziny, ochronie płodu ludzkiego i warunkach dopuszczalności przerywania ciąży oraz ustawy z dnia 6 czerwca 1997 r. - Kodeks karny [Journal of Laws of the Republic of Poland 2016 amending the Law of 7 January 1993 regarding the 
family planning, human embryo protection and conditions of permissibility of abortion and the Act of 6 June 1997 - Penal Code]. Available from: http://www.sejm.gov.pl/Sejm8.nsf/PrzebiegProc. xsp?id=6EDFF98AE25263E5C125801400298427.

3. Hassoun D, Jourdain A. Contraception and abortion in the countries of eastern Europe. Cah Sociol Demogr Med 1995; 35: 99-123.

4. Eurostat, 6 March 2012. Legally induced abortions by mother's age. Eurostat, on line. Available from: http://appsso.eurostat. ec.europa.eu/nui/show.do?wai=true\&dataset=demo_fabort (accessed 5 November 2016).

5. United Nations Department of Economic and Social Affairs, 2002. "Table 1. Live births by sex and urban/rural residence: 1980-1999", in United Nations Demographic Yearbook 1999 Natality Supplement, United Nations (New York, NY), on line at United Nations Statistics Division. Available from: http:// unstats.un.org/unsd/demographic/products/dyb/DYBNat/ NatStatTab01.pdf (accessed 5 November 2016).

6. Historical abortion statistics, Poland. compiled by Wm. Robert Johnston. Available from: http://www.johnstonsarchive.net/ policy/abortion/ab-poland.html (accessed 5 November 2016).

7. Miller K, Rosenfield A. Population and women's reproductive health: An International perspective. Annu Rev Public Health 1996; 17: 359-382.

8. Acosta CD, Bhattacharya S, Tuffnell D, et al. Terminations of pregnancy in Europe: the East-West divide. BJOG 2012; 1020. Version of Record online: 17 Jun 2012, DOI: 10.1111/j.1471-0528. 2012.03363.x.

9. Black Monday Poland - Protesting Restrictive Abortion Law. Gynaecology Centres Australia (GCA), 2016. Available from: http://gcaus.com.au/news/black-monday-poland-protestingrestrictive-abortion-law/ (accessed 6 November 2016).

10. Lesthaeghe R, Surkyn J. New forms of household formation in Central and Eastern Europe: Are they related to the newly emerging value orientations? Economic Survey of Europe 2002; 1: 197-216.

11. Billari F, Kohler HP. Patterns of low and lowest-low fertility in Europe. A Journal of Demography 2004; 58. Available from: http://www.tandfonline.com/doi/citedby/10.1080/0032472042 000213695?scroll=top\&ned Access=true (accessed 6 November 2016).

12. Andreas Hoff (ed.). Population Ageing in Central and Eastern Europe. Societal and Policy Implications. Farnham, UK \& Burlington, Ashgate 2011. Available from: https://books.google.pl/ books?id=HRHtCwAAQBAJ\&pg=PT56\&lpg=PT56\&dq=childbearing + in + Poland \&source $=$ bl\&ots $=q$ Eg73zOz8H\&sig $=t z x-$ E3VLsN_jO2bxxKTQhbyT3pg\&hl=pl\&sa $=X \& v e d=0 a-$ hUKEwiQ8dqM3JzQAhUH3SwKHV-mBXQ4FBDoAQhKMAc\# $\mathrm{v}=$ onepage $\& \mathrm{q}=$ childbearing $\% 20$ in $\% 20$ Poland \&f (accessed 6 November 2016).

13. Prognoza ludności na lata 2014-2050 (opracowana 2014 r.) GUS Available from: http://stat.gov.pl/obszary-tematyczne/ludnosc/ prognoza-ludnosci/prognoza-ludnosci-na-lata-2014-2050-opracowana-2014-r-,1,5.html (accessed 6 November 2016).

14. Dzieciuchowicz J, Janiszewska A. Demographic situation in Poland after 1990. In: Marszał T (ed.). Society and Space in con- temporary Poland in Łódź University Geographical Research. Łódź University Press, Łódź 2014; pp. 9-44.

15. Kimberly L, Case A, Cheung AP, et al. Advanced reproductive age and fertility: no. 269, November 2011. Int J Gynaecol Obstet 2012; 117: 95-102.

16. Hansen KR, Knowlton NS, Thyer AC, et al. A new model of reproductive aging: the decline in ovaria non-growing follicle number from birth to menopause. Hum Reprod 2008; 23: 699-708.

17. American College of Obstetricians and Gynecologists Committee on Gynecologic Practice; Practice Committee of the American Society for Reproductive Medicine. Female age-related fertility decline. Committee Opinion No. 589. Obstet Gynecol 2014; 123: 719-721.

18. Broekmans FJ, Soules MR, Fauser BC. Ovarian aging: mechanisms and clinical consequences. Endocr Rev 2009; 30: 465-493.

19. Reproductive Endocrinology and Infertility Committee; Family Physicians Advisory Committee; Maternal-Fetal Medicine Committee; Executive and Council of the Society of Obstetricians, Liu K, Case A. Advanced reproductive age and fertility. J Obstet Gynaecol Can 2011; 33: 1165-1175.

20. Broekmans FJ, Soules MR, Fauser BC. Ovarian aging: mechanisms and clinical consequences. Endocr Rev 2009; 30: 465-493.

21. Kimberly L, Case A, Cheung AP, et al. Advanced reproductive age and fertility: No. 269, November 2011. Int J Gynaecol Obstet 2012; 117: 95-102.

22. Bukulmez O, Aydin A. Assessment of ovarian reserve. Curr Opin Obstet Gynecol 2004; 16: 231-237.

23. Macintosh Kerry L. Teaching About the Biological Clock: Age-Related Fertility Decline and Sex Education, 2015. Available from: http://digitalcommons.law.scu.edu/cgi/viewcontent. cgi?article=1897\&context=facpubs (accessed 4 November 2016).

24. Ziebe S, Devroey P. State of the ART 2007 Workshop Group. Assisted reproductive technologies are an integrated part of national strategies addressing demographic and reproductive challenges. Hum Reprod Update 2008; 14: 583-592.

25. Hoorens S, Gallo F, Cave JAK, et al. Can assisted reproductive technologies help to offset population ageing? An assessment of the demographic and economic impact of ART in Denmark and UK. Hum Reprod 2007; 22: 2471-2475.

26. Leridon H, Slama R. The impact of a decline in fecundity and of pregnancy postponement on final number of children and demand for assisted reproduction technology. Hum Reprod 2008; 23: 1312-1319.

27. ESHRE Capri Workshop Group. Europe the continent with the lowest fertility. Hum Reprod Update 2010; 16: 590-602.

28. Cooke A, Mills TA, Lavender T. 2010. 'Informed and uninformed decision making' - women's reasoning, experiences and perceptions with regard to advanced maternal age and delayed childbearing: a meta-synthesis. Int J Nurs Stud 2010; 47: 13171329.

29. Spéder Z, Kapitány B. Failure to realize fertility intentions: A key aspect of the post-communist fertility transition. Population Research and Policy Review 2014; 33: 393-418.

30. Hart R, Norman RJ. The longer-term health outcomes for children born as a result of IVF treatment: Part I - General health outcomes. Hum Reprod Update 2013; 19: 232-243. 
31. American College of Obstetricians and Gynecologists Committee on Genetics and The Society for Maternal-Fetal Medicine Publications Committee. Noninvasive Prenatal Testing for Fetal Aneuploidy. Committee Opinion Number 545. December 2012. Available from: http://www.acog.org/Resources_And_Publications/ Committee_Opinions/Committee_on_Genetics/Noninvasive_Prenatal_Testing_for_Fetal_Aneuploidy (accessed 4 November 2016).

32. Gougeon A, Chainy GB. Morphometric studies of small follicles in ovaries of women at different ages. J Reprod Fertil 1987; 81: 433-442.

33. Hook EB. Frequency of Down Syndrome Per Maternal Age. JAMA 1983; 249: 2034-2038.

34. Pellestor F, Andreo B, Arnal F, et al. Maternal aging and chromosomal abnormalities: new data drawn from in vitro unfertilized human oocytes. Hum Genet 2003; 112: 195-203.

35. Warburton D. Biological aging and the etiology of aneuploidy. Cytogenet Genome Res 2005; 111: 266-272.

36. Dangel T. Wady letalne u płodów i noworodków - opieka paliatywna jako alternatywa wobec eugenicznej aborcji, eugenicznego dzieciobójstwa i uporczywej terapii. Fundacja Warszawskie Hospicjum dla Dzieci. Available from: http://www.hospicjum. waw.pl/pliki/Artykul/1246_sprawozdanie-2009.pdf (accessed 4 November 2016).

37. Cleland J, Bernstein S, Ezeh A, et al. Family Planning: the unfinished agenda. Lancet 2006; 368: 1810-1827.

38. Leridon H. Demographic effects of the introduction of steroid contraception in developed countries. Hum Reprod Update 2006; 12: 603-616.

39. Hoem J. Why does Sweden have such high fertility? MPIDR Working Paper WP 2005-09, April 2005. Available from: http://www.demogr.mpg.de/papers/working/wp-2005-009.pdf (accessed 4 November 2016).

40. Frejka T. Overview chapter 5: Determinants of family formation and childbearing during the societal transition in Central and Eastern Europe. Demographic Research 2008; 19: 139-170.

41. Wesolowski K. Maybe Baby? Reproductive Behavior, Fertility Intentions, and Family Policies in Post-Communist Countries, with a Special Focus on Ukraine. Digital Comprehensive Summaries of Uppsala Dissertations from the Faculty of Social Sciences 109.64 pp. Available from: https://www.diva-portal.org/smash/ get/diva2:789432/FULLTEXT01.pdf (accessed 4 November 2016).

42. United States Agency for International Development, 2014 The DHS Program, Demographic and Health Surveys. Available from: https://dhsprogram.com/pubs/pdf/FR307/FR307.pdf (accessed 4 November 2016).

43. National program "Reproductive Health of the Nation" for the period till 2015. Cabinet of Ministers' Dated 27 of December, 2006 \# 1849. Available from: http://tfh.jsi.com/Resources/Docs/ sprhn_2015.pdf (accessed 4 November 2016).

44. Bayrami R, Taghipour A, Ebrahimipoor H, et al. Investigating Women's Lifestyle during the Preconception Period in Kalat County, Iran. Journal of Midwifery and Reproductive Health 2014; 2 : 128-135.

45. Wojtyła C, Głuszek Ł, Biliński P, et al. Smoking during pregnancy - hematological observations in pregnant women and their newborns after delivery. AAEM 2012; 19: 836-841.
46. Ebadifar A, Hamedi R, KhorramKhorshid HR, et al. Parental cigarette smoking, transforming growth factor-alpha gene variant and the risk of orofacial cleft in Iranian infants. Iran J Basic Med Sci 2016; 19: 366-373.

47. Practice Committee of the American Society for Reproductive Medicine. Smoking and infertility. Fertil Steril 2004; 82 Suppl 1: S62-67.

48. Wojtyla A, Kapka-Skrzypczak L, Diatczyk J, et al. Alcohol-related Developmental Origin of Adult Health-population studies in Poland among mothers and newborns (2010-2012). AAEM 2012; 19: 365-377.

49. Wojtyła-Buciora P, Wojtyła A, Wojtyła C, et al. Prevalence of alcohol consumption according to high school students and their Barents. Hygeia Public Health 2012; 47: 498-504.

50. Finer LB, Zolna MR. Declines in Unintended Pregnancy in the United States, 2008-2011. N Engl J Med 2016; 374: 843-852.

\section{AUTHORS' CONTRIBUTIONS}

AW prepared the research concept, design of the publication and performed the data collection and assembly. AW and PB participated in data analysis and interpretation. AW wrote the article. PB prepared critical revision and finally approved it. 